\title{
KECENDERUNGAN GLOBAL DAN REGIONAL DALAM PEMANFAATAN TEKNOLOGI INFORMASI DAN KOMUNIKASI UNTUK PENDIDIKAN
}

\section{Abstrak}

Pemanfaatan Teknologi Informasi dan Komunikasi (TIK) untuk pendidikan sekarang ini sudah menjadi keharusan yang tidak dapat ditunda-tunda lagi. Beberapa contoh pemanfaatan TIK untuk pendidikan dalam perspektif global, regional dan nasional antara lain: (1) ASEAN SchoolNet, (2) EdukasNet, (3) Global Distance EducationNet (GDNet), dan sebagainya. Pendidikan dewasa ini dan masa mendatang ditandai dengan berbagai kecenderungan yang terkait dengan globalisasi, internasionalisasi dan transnasionalisasi pendidikan, yaitu berkenaan dengan meningkatnya kebutuhan masyarakat, tekanan perkembangan ekonomi, persoalan pemerataan dan perluasan akses serta tantangan untuk meningkatkan mutu, relevansi, daya saing, dan komitmen global dalam pendidikan. Kecenderungan global dan regional dalam pemanfaatan TIK untuk pendidikan masa depan akan lebih bersifat jaringan, terbuka dan dua arah, beragam, multidisipliner, serta terkait dengan produktifitas kerja dan kompetitif.

\section{A. LATAR BELAKANG MASALAH}

Perkembangan teknologi informasi dan komunikasi yang sangat pesat telah berpengaruh terhadap berbagai aspek kehidupan manusia. Sampai saat ini, menurut Alvin Toffler (1980) dalam Miarso

*) Drs. Bambang Warsita adalah staf Pusat Teknologi Informasi dan Komunikasi Pendidikan (PUSTEKKOM)-Departemen Pendidikan Nasional. 
$(2004)^{1}$, perkembangan tersebut telah mencapai gelombang yang ketiga. Gelombang pertama timbul dalam bentuk teknologi pertanian, dimana era pertanian ini telah berlangsung selama ratusan ribu tahun yang lalu bahkan sampai sekarang. Gelombang kedua timbul dalam bentuk teknologi industri, era industri ini telah berlangsung sejak ratusan tahun yang lalu sampai sekarang. Kini, gelombang ketiga yang ditandai dengan pesatnya perkembangan teknologi elektronika dan informatika. Perubahan dari era industri ke era informasi (global) ini hanya berlangsung dalam hitungan waktu tidak lebih dari setengah abad. Oleh karena itu kebijakan pendidikan diarahkan untuk menyiapkan sumberdaya manusia agar mampu menghadapi tantangan global, dengan memanfaatkan seluruh aspek sumberdaya yang ada termasuk pemanfaatan Teknologi Informasi dan Komunikasi (TIK).

Pemanfaatan TIK untuk pendidikan sudah menjadi keharusan yang tidak dapat ditunda-tunda lagi. Berbagai aplikasi teknologi informasi dan komunikasi sudah tersedia dalam masyarakat dan sudah siap menanti untuk dimanfaatkan secara optimal untuk keperluan pendidikan. Pemanfaatan teknologi informasi dan komunikasi untuk pendidikan dapat dilaksanakan dalam berbagai bentuk susuai dengan fungsinya dalam pendidikan. Fungsi teknologi informasi dan komunikasi dalam pendidikan dapat dibagi menjadi tujuh fungsi (Indrajit, 2004)2 ${ }^{2}$, yaitu: 1). sebagai gudang ilmu, 2). sebagai alat bantu pembelajaran, 3). sebagai fasilitas pendidikan, 4). sebagai standar kompetensi, 5). sebagai penunjang administrasi, 6). sebagai alat bantu manajemen sekolah, dan 7). sebagai infrastruktur pendidikan.

Dalam kaitan pemanfaatan TIK untuk pendidikan, Eric Ashby (1972) seperti dikutip oleh Miarso (2004) ${ }^{3}$, menyatakan bahwa dunia

1) Yusufhadi Miarso (2004), "Menyemai Benih Teknologi Pendidikan", (Jakarta: Prenada Media) hh 302-303.

2) Richardus Eko Indrajit, (2004), "Arsitektur Sekolah Modern Indonesia", Presentasi Sajian.

3) Yusufhadi Miarso (2004), loc. cit. hh 104-105. 
pendidikan telah memasuki revolusinya yang kelima. Revolusi pertama terjadi ketika orang menyerahkan pendidikan anaknya kepada seorang guru. Revolusi kedua terjadi ketika diguanakannya tulisan untuk keperluan pembelajaran. Revolusi ketiga terjadi seiring dengan ditemukannya mesin cetak sehingga materi pembelajaran dapat disajikan melalui media cetak dalam bentuk buku. Revolusi keempat terjadi ketika digunakannya perangkat elektronik seperti radio dan televisi untuk pemerataan dan peningkatan mutu pendidikan. Revolusi kelima, seperti saat ini, dengan dimanfaatkannya teknologi informasi dan komunikasi mutakhir, khususnya komputer dan internet untuk pendidikan. Revolusi ini memberi dampak terhadap beberapa kecenderungan global dan regional dalam pemanfaatan TIK untuk pendidikan masa depan.

Sekarang ini, dunia telah berada dalam era informasi dan komunikasi. Era informasi ditandai oleh pesatnya perkembangan TIK, khususnya radio, televisi, komputer dan internet. Internet merupakan jaringan global yang menghubungkan berjuta-juta jaringan komputer (local/wide areal network) termasuk komputer pribadi (stand alone), yang memungkinkan setiap komputer yang terhubung internet bisa saling melakukan komunikasi satu sama lain. Fasilitas aplikasi internet cukup banyak sehingga mampu memberikan dukungan bagi keperluan militer, kalangan media massa, kalangan bisnis, maupun kalangan pendidikan. Selanjutnya permasalahannya adalah bagaimana kecenderungan global dan regional dalam pemanfaatan TIK untuk pendidikan?

\section{B. PEMANFAATAN TEKNOLOGI INFORMASI DAN KOMUNIKASI UNTUK PENDIDIKAN \\ 1. Pengertian Teknologi Informasi dan Komunikasi untuk Pendidikan}

\section{a. Pengertian Teknologi}

Teknologi telah menjadi bagian integral dari setiap kehidupan masyarakat sejak ribuan tahun yang lalu. Pengembangan teknologi pada zaman batu dimaksudkan 
untuk mempermudah kehidupan manusia. Misalnya membuat kapak lonjong, membangun piramida, candi Borobudur, membuat api, alat penyimpan bahan makanan, senjata, dan sebagainya. Kemudian makin maju suatu budaya, makin banyak dan makin canggih teknologi yang ditemukan dan digunakan. Pengembangan dan pemanfaatan teknologi ini didorong oleh adanya keinginan untuk hidup yang lebih nyaman, lebih makmur dan lebih sejahtera.

Menurut asal usul kata teknologi berasal dari kata "techne" yang berarti cara dan "logos" yang berarti ilmu pengetahuan. Jadi teknologi berarti pengetahuan tentang cara. Dengan demikian teknologi adalah cara melakukan sesuatu untuk memenuhi kebutuhan manusia dengan memanfaatkan alat dan akal. Sedangkan menurut Jaques Ellul (1967) yang dikutif Miarso (2004) ${ }^{4}$ teknologi adalah keseluruhan metode yang secara rasional mengarah dan memiliki ciri efisiensi dalam setiap bidang kehidupan manusia.

Sedangkan pengertian teknologi pendidikan menurut Hackbarth (1996) yang dikutip Purwanto (2005) $)^{5}$ adalah konsep multidimensional yang meliputi: 1) suatu proses sistematis yang melibatkan penerapan pengetahuan dalam upaya mencari solusi yang dapat diterapkan untuk masalahmasalah dalam belajar mengajar, 2) produk seperti teks, program televisi, software komputer, 3) suatu profesi yang terdiri dari berbagai kategori pekerjaan, dan 4) merupakan bagian spesifik dari pendidikan.

\section{b. Pengertian Teknologi Informasi dan Komunikasi}

Perkembangan teknologi pendidikan tidak dapat dipisahkan dengan perubahan yang terjadi di bidan teknologi dan di

Yusufhadi Miarso (2004), op. cit. hh 131.

Purwanto, et.al. (2005), "Jejak Langkah Perkembangan Teknologi

Pendidikan di Indonesia“, (Jakarta: Pustekkom-Depdiknas), hh 13-15. 
bidang pendidikan. Di bidang teknologi sudah terjadi perkembangan yang luar biasa, seperti portofolio elektronik, game dan simulasi komputer, buku digital atau e-book, nirkabel (wireless) dan mobile computing. Ini semua telah memberikan peluang perubahan dan kemungkinan baru di bidang pendidikan. Berbagai jenis teknologi informasi dan komunikasi mutakhir tersebut telah melanda dan menyebabkan perubahan luar biasa dalam bidang pendidikan. Kemudian apa yang disebut dengan teknologi informasi dan komunikasi itu? Teknologi informasi adalah sarana dan prasarana (hardware, software, useware) sistem dan metode untuk memperoleh, mengirimkan, mengolah, menafsirkan, menyimpan, mengorganisasikan dan menggunakan data secara bermakna. Sedangkan teknologi komunikasi adalah sarana dan prasarana struktur kelembagaan dan nilai-nilai sosial dimana dikumpulkan, disimpan, diolah dan dipertukarkan informasi sehingga memungkinkan untuk terjadinya persamaan persepsi dan atau tindakan.

Perkembangan teknologi, khususnya TIK yang semakin pesat sangat berpengaruh besar terhadap pelaksanaan pendidikan secara nasional, regional dan global. Bahkan dapat menimbulkan permasalahan baru dalam dunia pendidikan. Akan tetapi TIK juga dapat membantu memecahkan permasalahan pendidikan secara nasional, regional dan global yang sedang kita hadapi. Apabila TIK itu dikembangkan atau diadopsi dan dikemas sesuai dengan prinsip-prinsip pembelajaran.

\section{Bentuk-Bentuk Pemanfaatan TIK untuk Pendidikan}

Berikut beberapa contoh pemanfaatan TIK untuk pendidikan dalam perspektif global, regional dan nasional.

\section{a. ASEAN SchoolNet}

Salah satu bentuk pemanfaatan TIK untuk pendidikan di 
sekolah adalah pengembangan jaringan sekolah atau ASEAN SchoolNet ${ }^{6}$. Jaringan sekolah atau SchoolNet adalah bentuk pemanfaatan TIK untuk pendidikan yang sangat transformatif mengkombinasi berbagai aspek pemanfaatan TIK ke dalam pembelajaran. Jaringan sekolah ini dapat menghubungkan sekolah, guru, orang tua siswa dan sumber belajar baik dalam lingkup nasional, regional maupun internasional. Selain itu adanya forum; database; pelatihan guru; interaksi antar para siswa dan para guru; serta proyek kolaboratif. Para guru dapat menggunakan TIK untuk keperluan administratif dan penilaian, disamping menghidupkan proses pembelajaran dan berbagi sumber belajar, inspirasi dan tantangan dengan guru lainnya.

Penggunaan TIK dan Internet di sekolah menyediakan suatu pintu gerbang ke informasi tanpa batas dan katalisator bagi dialog guru dan siswa di luar dinding kelas. Suatu jaringan sekolah (SchoolNet) memudahkan interaksi antar siswa dan guru serta mendorong keterlibatan dalam pengembangan kurikulum. Sebagai hasilnya akan memperluas basis sumber daya yang tersedia. SchoolNet dapat menghubungkan guru dan masyarakat yang tidak punya sarana, waktu, maupun uang untuk berkumpul bersama untuk berhubungan guna kemitraan dinamis. Mereka memperkuat ketrampilan dalam bekerja sama/ berkolaborasi dalam tim melalui aktivitas dan proyek-proyek telekolaborasi pada tingkat nasional, regional maupun global.

Pada skala lebih luas, SchoolNet telah mempercepat modernisasi sekolah dan sistem pendidikan berbasis teknologi. Mereka sudah membantu mengatasi kesenjangan digital dengan memobilisasi sektor teknologi informasi dan telekomunikasi untuk mengurangi biaya-

6) Ibid, Purwanto, et.al. (2005), hal. 238-243. 
biaya telekomunikasi dan pembebaskan biaya koneksi internet melalui berbagai pengaturan. Hal ini mendorong suatu perluasan jumlah sekolah yang dapat menggunakan telepon dan terhubung ke Internet; menurunkan rasio penggunaan komputer oleh siswa dan guru; dan meningkatkan akses guru dan siswa ke komputer melalui local-arear maupun wide-area networking yang lebih terbuka.

Idealnya, suatu jaringan sekolah (SchoolNet) menghubungkan kelas dari sekolah berbeda dan memberi kesempatan kepada siswa untuk bekerja sama dan berkolaborasi secara elektronik pada proyek kerjasama online. Dalam beberapa hal sistem jaringan di dalam suatu sekolah yang menghubungkan para siswa satu sama lain dan menyediakan akses kepada Internet adalah juga dikenal sebagai SchoolNet.

Umumnya, suatu jaringan sekolah menyediakan akses Internet dan dunia telekomunikasi untuk semua siswa. Hal ini membekali mereka dengan ketrampilan hidup dasar disamping kemampuan terkait dengan ketenaga-kerjaan. Hal ini juga membantu menjembatani organisasi, kemitraan, dan jejaring yang tergambar dengan ketersedian sumberdaya yang sangat luas di Internet. Para siswa terlibat dengan explorasi dan simulasi sebagai ganti menjadi penerima informasi pasif.

Para guru dan siswa menggunakan sarana berbasiskomputer seperti teks, grafik, editor, database, atau spreadsheet, yang mendekatkan mereka kepada gaya bekerja dan sarana yang digunakan dalam industri, perdagangan, dan kehidupan intelektual. Para guru mempunyai akses ke database penilaian siswa di mana data tentang peta pengetahuan masing-masing siswa disimpan. Data ini memungkinkan lingkungan belajar yang 
lebih efektif. Para guru sekarang mempunyai sarana untuk membuat keputusan pendidikan yang kompleks dan canggih yang didasarkan pada informasi terperinci.

Saat ini, UNESCO Bangkok sedang melaksanakan Proyek SchoolNet yang melibatkan keikutsertaan aktif Indonesia, Malaysia, Pilipina, Thailand, Kamboja, Myanmar, Laos PDR, dan Vietnam. Brunei akan mengambil bagian pada proyek ini atas biaya sendiri, sedangkan Singapura akan berperan sebagai narasumber. Proyek ini merupakan upaya untuk mempertunjukkan bahwa penggunaan TIK dalam pendidikan akan meningkatkan proses pembelajaran melalui pengintegrasian yang sistematis penggunaan TIK ke dalam kurikulum sains, matematika dan bahasa.

Di bawah proyek ini setiap negera mengembangkan atau meningkatkan jaringan sekolah masing-masing, sambil bekerja mewujudkan suatu SchoolNet regional yang akan menyatukan sumber belajar dan menghubungkan negaranegara itu dalam proyek belajar kolaboratif. Indonesia merupakan salah satu negara yang tergabung ke dalam ASEAN SchoolNet. Kegiatan ASEAN SchoolNet di Indonesia telah ditetapkan 3 sekolah rintisan yaitu SMA Negeri 1 Jakarta, SMA Negeri 1 Bogor, dan SMA Negeri 1 Gresik.

\section{b. EdukasiNet}

EdukasiNet merupakan salah satu bentuk pemanfaatan TIK untuk pendidikan yang berbasis internet. Dengan kata lain EdukasiNet sebagai salah satu media jaringan sekolah (schoolnet) di Indonesia. Jaringan sekolah adalah suatu kegiatan komunitas sekolah yaitu guru, siswa, atau tenaga pendidik dan kependidikan lain yang dimediasi oleh internet sebagai sarana komunikasi atau bertukar informasi satu sama lain. Terjadinya pertukaran informasi yang mudah dan cepat tanpa terbatas ruang dan waktu melalui program 
jaringan sekolah ini memungkinkan terjadinya komunitas masyarakat informasi (knowledge-based society) dalam lingkup sekolah. Dengan demikian, jaringan sekolah dapat dikatakan sebagai salah satu wahana untuk meningkatkan wawasan, pengetahuan, dan keterampilan komunitas sekolah yang pada akhirnya dapat membantu meningkatkan mutu pendidikan.

Program jaringan sekolah merupakan salah satu program unggulan UNESCO untuk diterapkan di berbagai negara di dunia. Bahkan ke depan diharapkan terjadi jaringan sekolah dalam skala nasional, regional dan internasional. Berkaitan dengan upaya itulah EdukasiNet diluncurkan pada tanggal 12 Agustus 2003 bertepatan dengan pencanangan bulan Telematika oleh Menteri Pendidikan Nasional dan Menteri Negara Komunikasi dan Informasi. EdukasNet ${ }^{7}$ adalah program jaringan sekolah yang dikembangkan oleh Pustekkom yang berfungsi sebagai 1 ) wahana komunikasi lintas sekolah; 2) wadah sumber belajar; dan 3) wahana berbagi informasi antar sekolah di Indonesia. Dengan tiga peran utama ini, maka EdukasiNet dapat berfungsi sebagai jaringan sekolah (schoolnet). Sebagai portal pendidikan, EdukasiNet dapat diakses oleh siapa saja, di mana saja dan kapan saja melalui url: http:// www.e-dukasi.net.

Beberapa alasan dikembangkannya EdukasiNet. Alasan pertama adalah untuk menjawab adanya kenyataan bahwa sampai dengan tahun 2002, sulit sekali ditemukan berbagai bahan belajar berbasis web yang berbahasa Indonesia dan sesuai dengan kurikulum. Saat itu, beberapa jaringan sekolah telah dikembangkan diantaranya adalah "Sekolah Online”, 'guru Online'. 'Jaringan Informasi Sekolah', dan lain-lain. Tetapi sebagian besar belum menyediakan bahan

7) Purwanto, et.al. (2005), op. cit. hal 175-178 
belajar (content) yang sesuai dengan kurikulum. Alasan kedua, internet memungkinkan untuk dapat mendistribusikan informasi dengan cepat tanpa mengenal ruang dan waktu. Oleh karena itu berbagai pengalaman, ide, berita atau informasi lain berkaitan dengan pendidikan dan atau pembelajaran yang berasal dari suatu sekolah, guru, para ahli dan lain-lain juga memungkinkan didistribusikan dengan cepat melalui internet. Alasan ketiga, dengan media internet, tidaklah mustahil antara guru dengan guru di sekolah yang berbeda, antara para ahli, siswa dengan guru di tempat berbeda dapat saling berkomunikasi baik secara langsung (synchronous) maupun tertunda (asynchronous) untuk mendiskusikan suatu topik/tema pembelajaran tertentu. Sehingga pertukaran pengetahuan dapat terjadi dan terdistribusi dengan cepat ke banyak sasaran secara efisien. Terjadinya pertukaran informasi yang mudah dan cepat tanpa batas ruang dan waktu melalui program jaringan sekolah (EdukasiNet) ini memungkinkan terjadinya komunitas masyarakat informasi (knowledge-based society) dalam lingkup sekolah.

Manfaat EdukasiNet bagi para penggunanya dapat dibedakan menjadi dua, yaitu sebagai berikut:

1) EdukasiNet sebagai Sumber Bahan Belajar

a) guru dan siswa dapat memperoleh berbagai bahan belajar yang meliputi semua mata pelajaran untuk SD, SMP dan SMA, modul online, pengetahuan populer, berita serta artikel pendidikan dengan cara mengunduh (mendownload) atau memanfaatkannya langsung dalam kelas;

b) siswa dapat menguji kemampuan/kompetensi semua mata pelajaran yang dipelajarinya secara online;

c) guru dapat memperoleh informasi mengenai teknik dan tips dalam belajar dan membelajarkan siswa 
d) guru dapat berbagi ilmu dengan guru lain dengan cara mengirimkan karyanya berupa bahan belajar berbasis web ke administrator EdukasiNet untuk di-upload;

2) EdukasiNet sebagai Sarana Komunikasi dan Kolaborasi Lintas Sekolah

a) Sekolah memperoleh ruang (space) untuk menampilkan web site sekolahnya masing-masing sebagai sub domain EdukasiNet;

b) Guru dapat berkomunikasi, berbagi ide dan pengalaman dengan sesama guru dari sekolah lain di Indonesia secara online dengan memanfaatkan fasilitas forum guru (melalui e-mail, millist atau chatting);

c) Guru dapat mengirimkan ide, pengalaman, karya ilmiah atau berita pendidikan ke adminstrator EdukasiNet untuk dipublish dalam feature artikel dan news EdukasiNet;

d) Siswa dapat berkomunikasi, berbagi ide dan pengalaman dengan sesama siswa dari sekolah lain dengan memanfaatkan fasilitas forum siswa;

EdukasiNet sebagai portal jaringan sekolah menyediakan: 1) bahan belajar (meliputi materi pokok, pengetahuan populer, modul online, dan uji kompetensi); 2) forum (meliputi forum diskusi untuk semua mata pelajaran, chatting dan milis; dan 3) informasi (yang meliputi artikel, berita, kalender kegiatan (event) dan web sekolah.

\section{c. Southeast Asia Global Distance Education Network}

Global Distance EducationNet (GDNet) ${ }^{8}$ ini dikembangkan sebagai sumber informasi dan pengetahuan tentang pendidikan jarak jauh untuk membantu klien World Bank

8) Purwanto, et.al. (2005),op. cit. hal 118-119 
dan pihak-pihak lain yang tertarik menggunakan pendidikan jarak jauh untuk pengembangan sumberdaya manusia. Jaringan ini terdiri atas situs inti terletak di the World Bank dan lima situs regional yaitu Asia Tenggara, Asia Timur, Afrika Selatan dan Amerika Tengah dan Eropa yang menggabungkan seluruh negara-negara di kawasan tersebut.

Situs Southeast Asia Global Distance Education Network (www.idln.or.id/gdnet) ini dikembangkan dalam kerangka kerjasama kerjasama antara World Bank dan Indonesian Distance Learning Network (IDLN). Situs tersebut secara khusus berperan dalam penyediaan dan penyebarluasan informasi tentang Pendidikan Jarak Jauh di kawasan Asia Tenggara. Artikel-artikel tentang pendidikan jarak jauh di Asia Tenggara yang dimuat, terbagi dalm empat kategori yaitu teaching learning. technlogy, policy and program, dan management. Pada setiap kategori terdapat artikel-artikel yang sesuai dengan kategori masing-masing. Data, informasi dan artikel yang terdapat pada situs ini dapat diakses oleh siapa saja dengan bebas. Situs ini terletak di server di Pustekkom karena kedudukan Pustekkom sebagai koordinator IDLN.

Selain contoh di atas berikut ini diberikan beberapa sampelsampel dari luar negeri hasil revolusi dari sistem pendidikan yang berhasil memanfaatkan TIK untuk menunjang proses pembelajaran ${ }^{9}$ antara lain sebagai berikut:

1) SD River Oaks di Oaksville, Ontario, Kanada, merupakan contoh tentang apa yang bakal terjadi di sekolah. SD ini dibangun dengan visi khusus: sekolah harus bisa membuat murid memasuki era informasi instan dengan penuh keyakinan. Setiap murid di setiap kelas berkesempatan untuk berhubungan dengan

sumber:www.pendidikan.net 
seluruh jaringan komputer sekolah. CD-ROM adalah fakta tentang kehidupan. Sekolah ini bahkan tidak memiiki ensiklopedia dalam bentuk cetakan. Di seluruh perpustakaan, referensinya disimpan di dalam disket video interktif dan CD-ROM-bisa langsung diakses oleh siapa saja, dan dalam berbagai bentuk: sehingga gambar dan fakta bisa dikombinasikan sebelum dicetak;foto bisa digabungkan dengan informasi.

2) SMU Lester B. Pearson di Kanada merupakan model lain dari era komputer ini. Sekolah ini memiliki 300 komputer untuk 1200 murid. Dan sekolah ini memiliki angka putus sekolah yang terendah di Kanada: 4\% dibandingkan rata-rata nasional sebesar $30 \%$.

3) Prestasi lebih spektakuler ditunjukkan oleh SMP Christopher Columbus di Union City, New Jersey. Di akhir 1980-an, nilai ujian sekolah ini begitu rendah, dan jumlah murid absen dan putus sekolah begitu tinggi hingga negara bagian memutuskan untuk mengambil alih. Lebih dari 99\% murid berasal dari keluarga yang menggunakan bahasa Inggris sebagai bahasa kedua. Bell Atlantic- Sebuah perusahaan telepon di daerah itu membantu menyediakan komputer dan jaringan yang menghubungkan rumah murid dengan ruang kelas, guru, dan administrator sekolah. Semuanya dihubungkan ke Internet, dan para guru dilatih menggunakan komputer pribadi. Sebagai gantinya, para guru mengadakan kursus pelatihan akhir minggu bagi orangtua. Dalam tempo dua tahun, baik angka putus sekolah maupun murid absen menurun ke titik nol. Nilai ujian-standar murid meningkat hampir 3 kali lebih tinggi dari rata-rata sekolah seantero New Jersey.

\section{Globalisasi, Internasionalisasi dan Regionalisasi Pendidikan}

Dalam alam modern saat ini kemajuan teknologi membuat yang tadinya tidak mungkin menjadi mungkin dikerjakan. Bayangkan 
dengan satu 'klik' mouse komputer, kita dapat menjelajahi dunia melalui situs website. Budaya, cara hidup, pola konsumsi, perilaku orang seantero jagad dapat dimonitor melalui internet. Di negeri ini telah terjadi suatu proses perubahan yang luar biasa dan tidak kalah dahsyatnya dibandingkan dengan gelombang tsunami. Arus informasi dari yang negatif sampai yang positif siap melanda kita semua. Salah-salah kita bisa kehilangan jatidiri kita. Inilah globalisasi yang siap atau tidak siap, suka atau tidak suka, kita harus menghadapinya serta mengantisipasinya dengan segala kekuatan dan penuh kesadaran.

Melalui media elektronik misalnya TV, radio, cellular phone/ SMS (short massaging service atau pesan singkat tertulis), dan sebagainya budaya kota telah masuk desa, budaya asing merambah ke seluruh pelosok nusantara, dan sebaliknya, dan tidak mudah bagi kita untuk menseleksinya mana yang bermanfaat maupun mana yang mudharat. Bahkan siaransiaran TV-pun banyak yang mencoba mengakomodir dan kadangkala tidak segan-segan meniru siaran TV luar negeri. Ada yang berupa acara permainan (game), gosip (ngomongin orang/ngrasani), jualan barang/jasa pariwara/iklan), kontes, dsb, dsb. Mulai dari anak di bawah umur sampai yang tua renta silahkan menikmati, boleh pilih mana yang disukai, semuanya tersedia hanya dengan menekan remote control.

Pendidikan Sekarang dan masa depan akan bercirikan pada: 1) belajar sepanjang hayat, 2) pemberdayaan peserta didik, 3) pembentukan watak dan peningkatan potensi secara optimal, 4) jeringan belajar dan pendidikan terbuka, 5) jaringan program dan kelembagaan, 6) pemanfaatan aneka sumber belajar, 7) kurikulum yang flexible dan aspiratif, 8) paradigma kelembagaan alternatif, 9) berasas manfaat dan kesetaraan, 10) mengutamakan profesionalisme dan pengembangan karir,

10) Yusufhadi Miarso (2004), op. cit. hh 666- 667. 
dan 11) keselarasan dengan kebutuhan dan lingkungan, serta 12) pemberdayaan teknologi.

Berbagai kecenderungan lain telah pula diramalkan oleh para futuris, Bishop G. (1989) dalam Miarso (2004) $)^{10}$ meramalkan bahwa pendidikan masa mendatang akan bersifat lebih luwes (flexible), terbuka dan dapat diakses oleh siapa saja yang memerlukannya tampa pandang faktor jenis usia, maupun pengalaman pendidikan sebelumnya. Mason R. (1994) berpendapat bahwa pendidikan mendatang akan lebih ditentukan oleh jaringan, bukannya gedung sekolah.

Menurut Suparman \& Zuhairi (2004)11 pendidikan dewasa ini dan masa mendatang ditandai dengan berbagai kecenderungan yang terkait dengan globalisasi, internasionalisasi dan transnasionalisasi pendidikan. Hal ini tentu menimbulkan beberapa konsekuensi, peluang dan tantangan berkenaan dengan meningkatnya kebutuhan masyarakat, tekanan perkembangan ekonomi, persoalan pemerataan dan perluasan akses serta tantangan untuk meningkatkan mutu, relevansi dan daya saing pendidikan. Kemudian hal-hal tersebut akan diuraikan lebih lanjut serikut ini.

\section{a. Globalisasi dan Internasionalisasi Pendidikan}

Tren globalisasi dan internasionalisasi pendidikan dewasa ini dan masa mendatang sulit untuk dihindarkan dalam bidang pendidikan. Mengingat adanya ketergantungan perekonomian antar negara. Pada hakekatnya, fenomena semacam ini telah ada semenjak sistem pendidikan diciptakan, walaupun tingkat intensitasnya menjadi meningkat dengan dimungkinkannya sistem informasi, komunikasi dan trasportasi global yang menjadi semakin

11) M. Atwi Suparman \& Aminudin Zuhairi (2004), "Pendidikan Jarak Jauh Teori dan Praktek", (Jakarta: Penerbit universitas Terbuka) hh 351-357. 
mudah dan murah. Selain itu karakteristik ilmu pengetahuan dan teknologi itu sendiri, pendidik dan peserta didik untuk saling berinteraksi, bermitra dan tentu bekerjasama dalam melakukan eksplorasi dan mendapatkan penemuan baru. Oleh karena itu sistem pendidikan manapun sulit untuk mengelak pengaruh dan dampak globalisasi dan internasionalisasi.

Bentuk internasionalisasi pendidikan ini bervariasi, mulai dari pengaruh yang bersifat ringan sampai dengan integrasi ke dalam fungís pendidikan, penelitian serta pelayanan masyarakat yang bersifat regional maupun internasional. Beberapa contoh antara lain penerimaan mahasiswa baru dari negara lain, mempekerjakan guru besar dari negara lain, penawaran dan pengembangan program studi internasional, pengembangan kampus di negara lain, pengembangan jeringan dan kemitraan dengan institusi di negara lain, jeringan institusi regional, dan pengembangan program pendidikan terbuka/jarak jauh transnasional. Sebagai contoh lain Sekarang ini Ditjen Manajemen Pendidikan Dasar dan Menengah, Depdiknas telah dan sedang mengembangkan dan merintis sekolah atau kelas yang berstandar nasional dan internasional di masingmasing provinsi dan secara berkelanjutan di masing-masing kabupaten/kota di seluruh Indonesia. Perkembangan dan pemanfaatan teknologi informasi dan komunikasi telah memperkaya karákter regional dan internasional berbagai institusi pendidikan.

Dalam konteks pendidikan dewasa ini pendidikan jarak jauh memiliki peranan yang penting. Sebagai ilustrasi, seorang peserta didik pada pendidikan jarak jauh di lokasi atau negara manapun ia menetap, untuk mengikuti suatu program pendidikan jarak jauh yang diselenggarakan oleh lembaga yang berkantor di wilayah negara mana pun, 
sejauh dimungkinkan adanya interaksi dan komunikasi melalui berbagai media. Dengan demikian penyelenggaraan pendidikan jarak jauh dapat menembus batas geografis dan politik suatu negara, dan bahkan boleh dikatakan melintasi batas negara manapun di dunia ini. Selain itu karena faktor bahasa dan budaya menjadi kendala dan sekaligus memberikan tantangan bagi institusi pendidikan jarak jauh dalam memberikan dan meningkatkan pemahaman lintas budaya.

\section{b. Perluasan Akses secara Universal pada Pendidikan}

Berdasarkan pembukaan UUD 1945 dinyatakan bahwa salah satu tujuan pemerintah Republik Indonesia adalah mencerdaskan kehidupan bangsa dan untuk itu setiap warga negara Indonesia berhak memperoleh pendidikan yang merata dan bermutu sesuai dengan minat dan bakat yang dimiliknya tanpa memandang status sosial, etnis dan gender. Jadi pendidikan merupakan hak setiap warga negara. Sekarang ini pendidikan bukan hanya kebutuhan tetapi hak dasar setiap warga negara dan bukan hanya menjadi keistimewaan sekelompok kecil anggota masyarakat tertentu tetapi hak warga masyarakat dari berbagai lapisan. Akses universal pada pendidikan menjadi agenda pokok pemerintah manapun di dunia, sejalan dengan kebutuhan membangun sumber daya manusia nasional berkualitas yang memiliki kompetensi tinggi untuk mampu bersaing dalam kancah regional dan global. Namur demikian, banyak negara berkembang masih harus menghadapi tantangan dalam meningkatkan akses dan partisipasi dalam pendidikan.

UUD 1945 mengamanatkan mengenai pentingnya pendidikan bagi seluruh warga negara seperti tertuang di dalam Pasal 28B Ayat (1) bahwa setiap orang berhak 
mengembangkan diri melalui pemenuhan kebutuhan dasarnya, berhak mendapatkan pendidikan dan mendapatkan manfaat dari ilmu pengetahuan dan teknologi, seni dan budaya demi meningkatkan kualitas hidupnya demi kesejahteraan umat manusia, dan Pasal 31 Ayat (1) bahwa setiap warga negara berhak mendapat pendidikan.

Dalam menjawab tantangan pemerataan dan perluasan akses terhadap pendidikan alternatifnya adalah pendidikan jarak jauh. Pemanfaatan teknologi informasi dan komunikasi memungkinkan lembaga pendidikan untuk mengembangkan berbagai bentuk penyampaian pendidikan. Sistem pendidikan yang flexibel dan terbuka menjadi alternatif dan cara yang efektif yang memungkinkan akses universal terhadap pendidikan.

Renstra Depdiknas ${ }^{12}$, Pemanfatan Teknologi Informasi dan Komunikasi sebagai sarana Pembelajaran Jarak Jauh; kegiatan prioritas ini ingin mengembangkan sistem pembelajaran jarak jauh (distance learning) di perguruan tinggi, pendidikan formal dan pendidikan nonformal untuk mendukung perluasan dan pemerataan pendidikan tinggi, pendidikan formal, dan pendidikan nonformal. Teknologi informasi dan komunikasi akan dimanfaatkan secara optimal dalam fungsinya sebagai media pembelajaran jarak jauh, dan juga untuk memfasilitasi manajemen pendidikan.

\section{c. Peningkatan Akses dan Partisipasi melalui Pendidikan Jarak Jauh}

Kebutuhan akan akses terhadap pendidikan dan globalisasi mendorong tumbuhnya pendidikan jarak jauh di berbagai jalur, jenis dan jenjang pendidikan. Akhir-akhir ini lembaga pendidikan jarak jauh mengalami perkembangan yang

12) Depdiknas, (2006), Rencana Strategis Departemen Pendidikan Nasional Tahun 2005-2009, Jakarta, hh 43. 
pesat dengan dimanfaatkannya internet dan teknologi informasi dan komunikasi. Selain itu pendidikan jarak jauh terus berkembang dengan makin banyaknya lembaga pendidikan modus ganda, yang menyelenggarakan program pendidikan tatap muka dan jarak jauh sekaligus. Dengan demikian memungkinkan peserta didik mempunyai pilihan yang flexibel untuk belajar tatap muka atau jarak jauh, memilih berbagai macam media dan belajar secara penuh waktu atau paruh waktu.

Regionalisasi dan internasionalisasi pendidikan juga telah mendorong penyelenggaraan pendidikan jarak jauh yang melintasi batas geopolitik negara. Bagi institusi pendidikan penyelenggaraan program pendidikan internasional dengan metode jarak jauh menjadi lebih mudah dengan memanfaatkan TIK.

\section{d. Komitmen Global dalam Pendidikan}

Komitmen pemerintah Indonesia ${ }^{13}$ dalam rangka mempercepat sasaran Konvensi Hak-Hak Anak (Convention on The Rights of the Child) yang menyatakan bahwa setiap negara di dunia melindungi dan melaksanakan hak-hak anak tentang pendidikan dengan mewujudkan wajib belajar pendidikan dasar bagi semua secara bebas dan konvensi mengenai HAM yang menyatakan "Setiap orang berhak atas pendidikan".

Pendidikan harus bebas biaya, setidaknya pada pendidikan dasar. Oleh karena itu pendidikan dasar harus bersifat wajib. Pendidikan teknik dan profesi harus tersedia secara umum dan pendidikan yang lebih tinggi harus sama-sama dapat dimasuki semua orang berdasarkan kemampuan (Deklarasi HAM). Hal ini sejalan degan pencapaian sasaran

13) Ibid. Depdiknas, (2006) hh 18-19. 
pembangunan pendidikan yang disepakati dalam Kerangka Aksi Dakar Pendidikan Untuk Semua (PUS) atau Education for All (EFA). Dalam sasaran Konvensi Hak-Hak Anak dan PUS, Pemerintah Indonesia telah metetapkan kebijakan dasar dan Program Nasional Bagi Anak Indonesia (PNBAI) tahun 2015, yaitu mewujudkan anak yang cerdas/ceria dan berakhlak mulia melalui upaya perluasan aksesibilitas, peningkatan kualitas dan efisiensi pendidikan, serta partisipasi masyarakat. Karena itu, kebijakan pendidikan perlu mengakomodasikan hak-hak anak dan kebutuhan anak termasuk juga mempertimbangkan tingkat pertumbuhan dan perkembangan anak.

Terkait dengan isu gender, ditetapkan pemihakan kebijakan dan disusun program-program pendidikan untuk mewujudkan kesetaraan dan keadilan gender. Artinya semua anak perempuan atau laki-laki memperoleh kesempatan belajar pada semua jalur, jenis dan jenjang pendidikan. Selain itu dibuka peluang yang sebesarbesarnya bagi laki-laki dan perempuan agar dapat melanjutkan ke jenjang pendidikan berikutnya dalam rangka mengembangkan seluruh potensi mereka secara optimal dan seimbang. Kebijakan ini telah mulai diwujudkan melalui program Pengarusutamaan Gender (PUG) untuk mencapai tujuan pembangunan milenium, di samping penuntasan wajib belajar pendidikan dasar 9 tahun yang bermutu dan bebas dari biaya.

Dalam kaitan pemihakan terhadap warga negara miskin yang mengalami hambatan dalam mengakses pendidikan, terutama bagi warga negara miskin yang berpotensi dan berkecerdasan istimewa perlu memperoleh beasiswa dan fasilitas lainnya, tanpa mengalami hambatan ekonomi secara berarti. Demikian pula, bagi warga negara yang memiliki kelainan khusus dan hambatan fisik dapat memperoleh layanan pendidikan yang bermutu sehingga 
mereka dapat mengembangkan potensinya secara optimal.

Diberlakukannya sistem perdagangan dunia akan memberikan peluang dan tantangan dalam meningkatkan mutu pendidikan dasar, menengah dan tinggi. Indonesia berkomitmen pada terbukanya perdagangan dunia (WTO), termasuk dalam perdagangan jasa atau General Agreement on Trade in Services (GATS) khususnya bidang pendidikan.

\section{Kecenderungan Global dan Regional dalam Pemanfaatan Teknologi Informasi dan Komunikasi untuk Pendidikan}

Kecenderungan masa depan dapat digambarkan sebagai berikut: 1) masyarakat informasi, 2) memanfaatkan teknologi tinggi dengan sentuhan yang halus, 3) penyusunan perencanaan jangka panjang, 4) desentralisasi, 5) demokrasi partisipasif, 6) pola jeringan, dan 7) pilihan majemuk.

Ada berbagai kecenderungan yang berkembang dalam pemanfaatan TIK khususnya dalam konteks regional dan global, tentunya dengan memperhatikan ketersediaan dan kemudahan akses sumber belajar online. Berikut ini beberapa kecenderungan atau tren yang berkembang sebagaimana disarikan dari artikel Newer Technologies for the Learning Society (C.Villanueva, 2000) ${ }^{14}$.

a. Secara umum, pengintegrasian secara penuh TIK kedalam pendidikan masih sangat terbatas. Multimedia interaktif atau hypermedia belumlah dimanfaatkan secara meluas. Aktivitas Online melibatkan internet dan intranet lebih banyak digunakan untuk keperluan komunikasi dari pada sarana pendidikan interaktif.

b. Model pembelajaran campuran yang baru mulai muncul. Pembelajaran tatap muka dan aktivitas belajar online, video,

14) Purwanto, et.al. (2005),op. cit. hal 234-237. 
multimedia dan sarana telekomunikasi menunjang berbagai proses pembelajaran, kadangkala dalam bentuk kombinasi dan kadangkala dalam bentuk yang lebih terintegrasi.

c. Pendidikan jarak jauh sekarang disajikan dalam dua cara yaitu synchronous mode di mana peserta didik menggunakan TIK untuk berkomunikasi pada waktu yang bersamaan dan asynchronous mode di mana para peserta didik belajar atau berkomunikasi secara mandiri pada waktu yang berbeda kapan saja mereka online (anytime-anywhere learning). Dalam kenyataannya pertemuan tatap muka atau interakasi (synchronous) masih diperlukan untuk menunjang belajar mandiri dan asynchronous agar belajar dapat lebih efektif. TIK memfasilitasi interaksi tingkat tinggi antara siswa, guru, dan materi pembelajaran berbasis komputer. Komunikasi dapat dinamis dan bervariasi sesuai keinginan siswa dan guru, dan ia dapat terjadi dalam berbagai bentuk seperti e-mail, mailing list, chat, bulletin board, and konferensi komputer.

d. TIK sudah menjadi suatu daya penggerak perubahan bidang pendidikan dan sekaligus menjadi bagian integratif dari kebijakan dan rencana pendidikan nasional. Bukti yang berkembang menunjukkan semakin banyak negara yang mulai melengkapi sekolah mereka dengan komputer untuk mencapai reformasi sekolah atau usaha peningkatan sekolah atau bahkan untuk memberi sekolah mereka suatu penampilan modern dan berteknologi. Bagaimanapun, dalam posisi ini banyak pendidik yang melihat teknologi online sebagai suatu jalan untuk pengajaran, pelajaran, dan praktek penguasaan baru, hanya mempunyai sedikit informasi tentang potensi dan penggunaan otentik dari TIK dalam pendidikan.

e. Pengalaman menunjukkan bahwa pengenalan tentang teknologi di sekolah mengalami tiga fase, yakni suatu tahap penggantian di mana praktek tradisional masih terjadi tetapi teknologi baru digunakan; suatu tahap transisi di mana praktek baru mulai muncul dan praktek lama dipertanyakan; 
dan suatu tahap transformasi di mana teknologi memungkinkan praktek baru dan praktek lama menjadi usang. Jika pendidik meminta dengan tegas atas penggunapan TIK sebagai pengganti praktek yang ada, mereka tidak dapat berperan untuk memecahkan permasalahan di bidang pendidikan yang saat ini mereka temui.

f. Pengenalan TIK di sekolah telah membawa suatu sikap yang lebih positif terhadap sekolah pada diri siswa. Karena TKI dan belajar berbasis web menawarkan keanekaragaman yang lebih besar dari tujuan, proyek, aktivitas, dan latihan dalam pembelajaran dibanding kelas tradisional, minat dan motivasi siswapun meningkat secara nyata.

g. Para guru dan siswa terangsang karena pengajaran menjadi lebih dinamis yang memperluas visi mereka seperti halnya akses ke bahan belajar dan perangkat lunak bidang pendidikan yang bermutu tinggi. Lebih dari itu, para guru kelihatannya termotivasi untuk mengajar dengan lebih kreatif. Portal pembelajaran menghubungkan para guru kepada sejumlah racangan pembelajaran, panduan guru, dan soal-soal latihan siswa yang ditempatkan di Internet oleh institusi pemerintah, LSM, dan institusi pendidikan.

h. Kelas online cenderung untuk menjadi lebih sukses jika TIK dikombinasikan dengan suatu ilmu pendidikan yang tepat. Gelanggang pendidikan dari pembelajaran online masih sangat muda. Saat banyak institusi yang menawarkan kursus online, pemahaman mendalam tentang isu pedagogis yang berhubungan dengan pendidikan online masih belum diselidiki secara mendalam.

i. Banyak kursus online yang hanya halaman web dikombinasikan dengan e-mail dan ruangan chatting tanpa landasan pedagogis. Pengalaman-pengalaman sukses menunjukkan bahwa telah ada suatu penurunan dari aktivitas dipandu guru seperti halnya penurunan jumlah pembelajaran tatap muka dan bergerak ke arah aktivitas 
yang berbentuk proyek dan pembelajaran mandiri sebagai hasil pemanfaatan TIK.

j. Pembelajaran online memungkinkan siswa mempunyai kendali lebih besar terhadap kegiatan dan isi pembelajaran. Lingkungan online mennempatkan siswa di tengah-tengah pengalaman belajar. Pada pembelajaran tradisional, pengulangan digunakan berkali-kali dengan memperkenalkan informasi yang sangat serupa dalam format berbeda atau dengan menanyakan pertanyaan yang sama dengan cara yang berbeda. Padahal banyak siswa tidak suka latihan yang berulang-ulang.

k. Internet mendorong siswa untuk menggali informasi dan contoh praktis. Hypermedia dan multimedia memudahkan pendekatan yang belum pernah terjadi pada pembelajaran tradisional.

I. Internet mempromosikan suatu alternatif jenis belajar dengan melakukan (learning by doing) di manapara siswa diminta untuk melakukan proyek yang berhubungan dengan situasi hidup nyata. Teknologi menyampaikan informasi dengan penekanan pada penciptaan dan explorasi aktif terhadap pengetahuan dibandingkan transfer informasi searah, yang memungkinkan siswa tersebut untuk menggunakan secara penuh kemampuan kognitif mereka sendiri.

m. Corak interaktif sumber belajar memungkinkan siswa untuk terus meningkatkan keterlibatannya dengan pengembangan isi dan dengan demikian berperan dalam suatu situasi belajar yang lebih otentik. Sebagai contoh, para siswa dapat mengakses perpustakaan maya di seluruh dunia. Dengan demikian mereka mempunyai akses ke sejumlah besar informasi dan sumber belajar yang luas yang tidak dapat dicapai dalam seting pembelajaran yang tunggal.

n. Sejauh yang terkait dengan guru, sejumlah besar sumber belajar yang diletakkan di Internet telah membantu guru dalam menghadapi tantangan mengajar sehari-hari. Para 
guru dapat saling betukar rencangan pembelajaran, teknik pedagogis, dan strategi yang berhubungan dengan isu-isu dan permasalahan umum.

o. Pembelajaran online menyediakan perkakas teknis yang membuat belajar lebih mudah. Sebagai contoh, bahasa yang digunakan untuk mencari informasi dan bahan belajar adalah segera dan intuitif. Bahasa tersebut tidaklah harus dipelajari oleh pemakai dan dapat diadopsi dengan usaha minimal. Tatabahasa Dan sintaksis dasar dapat digunakan sebagai instrumen untuk mencari dan memperoleh informasi.

p. Pengintegrasian komunikasi dan authoring tools, bersama dengan alat penghubung click-to-connect telah berhasil dengan mantap mempermudah proses mengecek email, mengakses data, dan pengaturan atas koneksi konferensi komputer. Teknologi simulasi tau visualisasi dapat membantu siswa untuk belajar sistem yang kompleks dengan cara yang lebih kongkrit. Komunikasi percakapan berbasis komputer (Computer Mediated Chatting = CMC) dan bulletin board dapat melengkapi pertemuan tatap muka.

q. Pendidikan dan pelatihan guru sekarang meliputi pembelajaran kolaboratif dan just-in-time. TIK membuka suatu dunia yang utuh dari belajar sepanjang hayat melalui pendidikan jarak jauh, pembelajaran asynchronous, dan pelatihan atas permintaan. TIK cukup fleksibel untuk memperkenalkan kursus baru sebagai jawaban langsung atas permintaan yang semakin meningkat.

r. TIK membantu memecahkan isolasi profesional yang banyak diderita para guru. Dengan TIK, mereka dapat dengan mudah berhubungan dengan para profesional lain, rekan kerja, penasihat, universitas dan pusat keahlian, dan dengan sumber belajar. Para guru kini menerbitkan bahan belajar yang mereka kembangkan di Internet dan berbagi pengalaman mengajar mereka dengan guru lainnya.

s. Penggunaan jaringan komputer untuk mempromosikan 
aktivitas belajar berkelompok menjadi semakin lebih populer. Teknologi komputer dalam pendidikan bergerak dari belajar mandiri ke metode belajar jarak jauh berkelompok. Dengan menggunaan perangkat komunikasi berbasis komputer dan kelompok belajar berbasis web, siswa dapat menerapkan pengetahuan yang dimiliknya dengan mengkombinasikan usaha mereka untuk mengembangkan suatu aktivitas atau proyek. Belajar koperatif melalui komputer mempunyai efek positif atas kinerja tugas kelompok, prestasi individu, dan sikap terhadap belajar kolaboratif.

t. Universitas sedang memasuki fase kemitraan dengan sektor swasta, terutama sekali industri teknologi informasi, dalam rangka membantu menjaga kelangsungan hidup operasi dan keuangan dari program pendidikan berbasis TIK. Semakin banyak sekolah menyadari bahwa berhubungan dengan sektor bisnis tidak akan mengancam sistem persekolahan. Yang lain melihat suatu keuntungan dalam capitalising atas produk dan jasa pendidikan mereka. Persekutuan belajar di penyampaian produk dapat menawarkan berbagai manfaat, seperti pengurangan biaya-biaya pengembangan latihan, berbagi biaya-biaya penelitian dan pengembangan yang bersama, atau berbagi database dan isi perpustakaan.

u. TIK meningkatkan fungsi perpustakaan dan mengubah peran pustakawan secara hakiki. Sekolah tidak perlu melanjutkan penderitaan atas kelangkaan pendukung perpustakaan dengan memanfaatkan sumber belajar yang kaya yang tersedia di Internet.

Dalam pemanfaatan TIK untuk pendidikan ini akan memberi dampak terhadap beberapa kecenderungan pendidikan masa depan. Beberapa ciri tersebut digambarkan oleh Miarso (2004) ${ }^{15}$

5) Yusufhadi Miarso (2004),op. cit. hh 665- 666.

16) Steve Ryan, at. al. (2000), "The Virtual University: the Internet and Resources-Based Learning", (Lodon, UK: Kogan Page Ltd.). 
khususnya dalam pendidikan tinggi adalah sebagai berikut:

a. Berkembangnya pembelajaran di luar kampus sebagai bentuk pendidikan berkelanjutan.

b. Orang memperoleh akses lebih besar dari berbagai sumber belajar.

c. Perpustakaan sebagai pusat sumber belajar menjadi ciri dominan dalam kampus.

d. Bangunan kampus berserak (tersebar) dari kampus inti di pusat dengan kampus satelit yang ada di tengah masyarakat.

e. Tumbuhnya profesi baru dalam dalam bidang media dan teknologi.

f. Orang dituntut lebih banyak belajar mandiri.

Kecenderungan lain, seperti diungkapkan oleh Ryan et al $(2000)^{16}$ adalah sebagai berikut:

a. Teknologi yang ada saat ini dapat mentransformasi cara pengetahuan dikemas, disebarkan, diakses, diperoleh dan diukur. Sehingga merubah cara produksi dan penyampaian materi dari cetak dan analog ke dalam bentuk digital dalam bentuk DVD, CD-ROM, maupun bahan belajar on-line berbasis web lainnya.

b. Orang akan lebih memilih metode belajar yang lebih luwes (flexible), mudah, dan sesuai dengan kebutuhan dan kondisinya masing-masing. Sehingga memicu terjadinya pergeseran pola pendidikan dari tatap muka (konvensional) kearah pendidikan yang lebih terbuka.

Pemanfaatan dan pendayagunaan TIK harus menjadi pemandu atau menjadi trend setter dalam era kedepan baik secara nasional, regional maupun global. Selanjutnya bagaimana menjadikan inovasi, networking, dan teknologi menjadi suatu model bagi pengelolaan dan pengembangan pendidikan masa depan. Perlu kita sadari bahwa TIK bukan sekedar alat teknologi

17) Depdiknas, (2006) op. cit. Hh 48 dan 65. 
perangkat keras, bukan sekedar tools/alat. TIK adalah budaya, sebuah kultur. Dan lalu bagaimana kita dapat hijrah (changing our culture), dari yang belum kenal TIK menjadi kecanduan TIK, dari yang belum butuh menjadi butuh atau menjadi tergantung ICT. Budaya ICT ini harus kita create.

Dewasa ini pemanfaatan TIK sudah mulai menjadi perhatian banyak pihak baik secara nasional, regional maupun global. Renstra Depdiknas 2005-2009 ${ }^{17}$, Pengembangan dan pendayagunaan teknologi informasi dan komunikasi untuk peningkatan mutu, relevansi, dan daya saing. Di masa depan diharapkan dapat memberikan dampak bagi perwujudan eksistensi manusia dan interaksinya sehingga dapat hidup bersama dalam keragaman sosial dan budaya. Selain itu, upaya peningkatan mutu dan relevansi dapat meningkatkan taraf hidup masyarakat serta daya saing bangsa.

Mutu pendidikan juga dilihat dari meningkatnya penghayatan dan pengamalan nilai-nilai humanisme yang meliputi keteguhan iman dan takwa serta berahlak mulia, etika, wawasan kebangsaan, kepribadian tangguh, ekspresi estetika, dan kualitas jasmani. Peningkatan mutu dan relevansi pendidikan diukur dari pencapaian kecakapan akademik dan non-akademik yang lebih tinggi yang memungkinkan lulusan dapat proaktif terhadap perubahan masyarakat dalam berbagai bidang baik ditingkat lokal, nasional maupun global.

\section{KESIMPULAN}

1. Sekarang ini kita telah berada dalam era informasi dan komunikasi yang ditandai dengan pesatnya perkembangan TIK, khususnya radio, televisi, komputer dan internet yang dapat digunakan atau dimanfaatkan untuk keperluan militer, kalangan media massa, kalangan bisnis, maupun kalangan pendidikan.

2. Perkembangan TIK yang sangat pesat berpengaruh besar terhadap pelaksanaan pendidikan secara nasional, regional 
dan global apabila dikembangkan atau diadopsi dan dikemas sesuai dengan prinsip-prinsip pembelajaran.

3. Contoh bentuk pemanfaatan TIK untuk pendidikan dalam perspektif global, regional dan nasional yaitu: 1) ASEAN SchoolNet, 2) EdukasNet, 3) Global Distance EducationNet (GDNet), dan sebagainya.

4. ASEAN SchoolNet adalah jaringan sekolah yang memanfaatkan TIK untuk pendidikan yang mengkombinasi berbagai aspek ke dalam pempelajaran yang dapat menghubungkan sekolah, guru, orang tua siswa dan sumber belajar baik dalam lingkup nasional, regional maupun internasional.

5. EdukasiNet adalah portal jaringan sekolah di Indonesia yang dikembangkan oleh Pustekkom yang dapat diakses melalui url: http://www.e-dukasi.net dengan menyediakan 1) bahan belajar (meliputi materi pokok, pengetahuan populer, modul online, dan uji kompetensi); 2) forum (meliputi forum diskusi untuk semua mata pelajaran, chatting dan milis; dan 3) informasi (yang meliputi artikel, berita, kalender kegiatan (event) dan web sekolah.

6. Southeast Asia Global Distance Education Network dikembangkan dalam kerangka kerjasama antara World Bank dan Indonesian Distance Learning Network (IDLN) untuk menyediakan dan menyebarluaskan informasi tentang Pendidikan Jarak Jauh di kawasan Asia Tenggara berupa artikel dalam empat kategori yaitu teaching learning. technlogy, policy and program, dan management.

7. Pendidikan dewasa ini dan masa mendatang ditandai dengan berbagai kecenderungan yang terkait dengan globalisasi, internasionalisasi dan transnasionalisasi pendidikan, yaitu berkenaan dengan meningkatnya kebutuhan masyarakat, 
tekanan perkembangan ekonomi, persoalan pemerataan dan perluasan akses serta tantangan untuk meningkatkan mutu, relevansi, daya saing dan komitmen global dalam pendidikan.

8. Kecenderungan global dan regional dalam pemanfaatan TIK untuk pendidikan pada masa depan akan lebih bersifat jaringan, terbuka dan dua arah, beragam, multidisipliner, serta terkait dengan produktifitas kerja dan kompetitif.

\section{DAFTAR PUSTAKA}

Cronin, Mary J., 1996, The Internet Strategy Hanbook: Lessons from the New Frontier Business, Library of Congress, USA

Dryden, Gordon \& Voss, Jeannette (1999), "the Learning Revolution: to Change the Way the World Learns", (Torrance, California, USA: The Learning Web).

Depdiknas, (2006), Rencana Strategis Departemen Pendidikan Nasional Tahun 2005-2009, Jakarta

Indrajit, Richardus Eko (2004), "Arsitektur Sekolah Modern Indonesia", Presentasi Sajian.

Miarso, Yusufhadi (2004), "Menyemai Benih Teknologi Pendidikan", (Jakarta: PRENADA MEDIA).

Purbo, Onno W., 1996, Internet untuk Dunia Pendidikan, Makalah, Institut Teknologi Bandung, Bandung

Purwanto, dkk (2005), "Jejak Langkah Perkembangan Teknologi Pendidikan di Indonesia", (Jakarta: Pustekkom-Depdiknas).

Pusat Teknologi Komunikasi dan Informasi Pendidikan, Departemen Pendidikan Nasional (2005), "Panduan Pemanfaatan EdukasiNet". (Jakarta: Pustekkom)

Project in ASEAN Setting", available at http://www.unescobkk.org/index.php

Ryan, Steve, at.. al. (2000), "The Virtual University: the Internet and ResourcesBased Learning", (Lodon, UK: Kogan Page Ltd.).

Suparman, M. Atwi \& Zuhairi, Aminudin (2004), "Pendidikan Jarak Jauh Teori dan Praktek", (Jakarta: Penerbit universitas Terbuka)

Tung, Khoe Yao., 2000, Pendidikan dan Riset di Internet, Strategi Meningkatkan Kualitas SDM dengan Riset dan Pendidikan Global Melalui Teknologi Informasi, (Jakarta : PT Dinastindo)

UNESCO-Bangkok, (2004), "Strengthening ICT use in Schoool and SchoolNet". 